\title{
Advantages and limitations of exergy indicators to assess sustainability of bioenergy and biobased materials
}

\author{
Dries Maes ${ }^{*}$, Steven Van Passel ${ }^{1}$ \\ Hasselt University, Centre for Environmental Science, Belgium, Agoralaan, Gebouw D, 3590 Diepenbeek, Belgium
}

\section{A R T I C L E I N F O}

\section{Article history:}

Received 2 April 2013

Received in revised form 3 October 2013

Accepted 14 November 2013

Available online $\mathrm{xxxx}$

\section{Keywords:}

Cumulative exergy content

Bioenergy

Biobased materials

Sustainability assessment

Composite indicators

\begin{abstract}
A B S T R A C T
Innovative bioenergy projects show a growing diversity in biomass pathways, transformation technologies and end-products, leading to complex new processes. Existing energy-based indicators are not designed to include multiple impacts and are too constrained to assess the sustainability of these processes. Alternatively, indicators based on exergy, a measure of "qualitative energy", could allow a more holistic view. Exergy is increasingly applied in analyses of both technical and biological processes. But sustainability assessments including exergy calculations, are not very common and are not generally applicable to all types of impact. Hence it is important to frame the use of exergy for inclusion in a sustainability assessment. This paper reviews the potentials and the limitations of exergy calculations, and presents solutions for coherent aggregation with other metrics. The resulting approach is illustrated in a case study.

Within the context of sustainability assessment of bioenergy, exergy is a suitable metric for the impacts that require an ecocentric interpretation, and it allows aggregation on a physical basis. The use of exergy is limited to a measurement of material and energy exchanges with the sun, biosphere and lithosphere. Exchanges involving services or human choices are to be measured in different metrics. This combination provides a more inclusive and objective sustainability assessment, especially compared to standard energy- or carbon-based indicators. Future applications of this approach in different situations are required to clarify the potential of exergy-based indicators in a sustainability context.
\end{abstract}

(c) 2013 Elsevier Inc. All rights reserved.

\section{Introduction}

Renewable energy projects form an essential part to confront growing climate and energy supply concerns, but these projects have important environmental impacts. Environmental impacts are commonly assessed by one-dimensional indicators such as $\mathrm{CO}_{2}$-reductions or energy-based indicators. For instance on a European level, sustainability guidelines are imposed through the directive 2009/28/EC and the related COM/2010/11 providing guidelines for climate impact assessment for various renewable energy pathways based on $\mathrm{CO}_{2}$-emissions and $\mathrm{CO}_{2}$-equivalents only. More inclusive assessments of bioenergy production can be based on Life Cycle Analysis (LCA), such as the Ecoindicator 99 (Goedkoop et al., 1999) which gathers impacts in three large domains of damage: damage to mineral and fossil resources, damage to ecosystem quality and damage to human health. Zah et al. (2007) further aggregate the different damage domains and subdomains to one indicator:

However, current evolutions in the technological developments for the production of bioenergy and biobased materials pose three

\footnotetext{
* Corresponding author. Tel.: +32 112687 44; fax: +32 11268700.

E-mail addresses: Dries.Maes@uhasselt.be (D. Maes), Steven.Vanpassel@uhasselt.be (S. Van Passel).

1 Tel.: + 32112687 46; fax: +3211268700.
}

challenges for these environmental assessment methods. First, technological developments in the production of bioenergy and biobased materials use multiple biomass provision pathways, combined with a growing variety of transformation processes and alternative uses of end-products. New combustion projects not only focus on clean sawdust or wood particles, but also on polluted streams or mixed agricultural waste flows (Junginger et al., 2008; Nzihou and Stanmore, 2013). Fermentation projects combine various flows of biomass, such as roadside clippings, municipal waste and industrial by-products (Pick et al., 2012; Weiland et al., 2009). These projects produce energy flows such as heat and electricity, but increasingly produce other outputs as well, such as fertilisers, liquefied biogas, purified $\mathrm{CO}_{2}$ or animal fodder (Van Dael et al., 2013). Increasing interest in integrated biorefineries amplifies these trends of diversification and higher complexity (Bozell, 2008; Fatih Demirbas, 2009; Warner et al., 2004). As a result, sustainability assessment methods are not equipped to take into account all relevant impacts with these intertwined complex production pathways. Secondly, energy-based methods face fundamental difficulties when biobased materials are produced simultaneously with bioenergy. And finally, there is a growing need to include aspects beyond climate change in sustainability assessments (Evans et al., 2009). Particularly carbon and $\mathrm{CO}_{2}$-centred methods are limited to describe the integration of agriculture in the project life cycle. Agricultural practise impacts environmental aspects such as nitrate and phosphate 
use, water use, soil fertility, and erosion and it depends on numerous ecosystem services. LCA-based approaches are already more inclusive, but result in disparate indicators for impacts on eutrophication, GHG emissions, human health, biodiversity, etc. The aggregation of these indicators can be done mathematically or by weighing (Daniel et al., 2004; Zah et al., 2009). But generalisation or comparison of these aggregations is hard, as these approaches often are very context-specific (Soares et al., 2006). And aggregation within a standard LCA is a complex and controversial issue (Benetto et al., 2007).

Indicators based on exergy can remediate some of these shortcomings. Exergy is being applied as a useful metric in environmental impact assessments (Banerjee and Tierney, 2011; Chen et al., 2009; Hau and Bakshi, 2003; Hepbasli, 2008; Kirova-Yordanova, 2010; Yi et al., 2004). It can account for materials and energy flows alike and can be used for the analysis of complex production pathways (Apaiah et al., 2006; Bakshi, 2000; Huang et al., 2007; Zhang and Chen, 2010). However, the integration of exergy-based environmental impact measures is not straightforward, due to both technical limitations and theoretical limitations. Various different applications of exergy exist, but not all are appropriate within the framework of a sustainability assessment. This paper gathers different solutions for exergy-based indicators proposed in literature and evaluates the possible inclusion in a sustainability assessment for bioenergy projects. The resulting approach is illustrated in a short case study.

Bioenergy, being a broad term, is defined here as the production of electricity or heat as a result of a physical transformation of biological material. Transformations can be based on combustion, gasification, pyrolysis, or digestion for instance. The methods and indicators discussed are suitable to more complex technological processes with multiple outputs, such as hybrid processes, biorefineries or the production of biobased materials with energy as a by-product. Our research highlights the advantages and limitations of exergy-based measures in this respect. Section 2 defines exergy, describes advantages, and reviews divergent practices. Section 3 determines limitations for the application of exergy-based measures to assess environmental impacts. Section 4 presents all required aspects for an inclusive sustainability assessment and solutions to integrate exergy-based measures in the total assessment. Section 5 illustrates the methodology depending on different choices with a short case study. Section 6 concludes.

\section{Exergy-based indicators within a life cycle context}

Exergy or 'available energy' has been defined as "the maximum amount of useful work that can be obtained from [a] system or resource when it is brought to equilibrium with the surroundings through reversible processes in which the system is allowed to interact only with the environment" (Dewulf et al., 2008). Three points should be highlighted. First, whereas the term "energy" counts all energy flows regardless of their working potential, exergy only considers the highly qualitative, useful part of energy (Dincer, 2002). Second, exergy, contrary to energy, is not preserved. The exergy content of a flow changes when energy forms are transformed from one into another. Because these transformations always cause exergy destruction, the amount of exergy destruction in a process is also a measure of efficiency. Third, energy forms are interpreted thermodynamically and include all possible forms such as chemical, mechanical, thermal, electrical or potential energy. This means that exergy equally accounts for materials, movements, currents or heat and the transformations between them. Especially the inclusion of all chemical substances is interesting.

\subsection{Objective valuation of energy and materials}

The standard method to utilise exergy within a life cycle context is the calculation of the Cumulative Exergy Content (CEC) (Szargut et al., 1988). The CEC accounts for the cumulative quantity of exergy used during the life cycle of a product. Its applicability is very broad because it includes exergy streams not only from energy flows, but also for material inputs for the process, such as fuels, minerals or gases. This approach forms the basis of all further exergy calculations in a life cycle context (Bösch et al., 2007; Szargut, 2005) and has been widely applied in numerous domains (Sciubba and Wall, 2007). The Cumulative Exergy Extraction from the Natural Environment (CEENE) further extends the CEC to include organic resources extracted from ecosystems as well (Dewulf et al., 2007).

The generalised thermodynamical basis for the determination of the exergy values, ensures that different exergy results can be directly added and compared. For instance, comparing the intrinsic exergy content of wood particles and exergy in heat generated by wood burning, shows that combustion destroys a large part of the initial value of the wood.

As Gasparatos et al. (2008) note, one apparent disadvantage is that a reference framework is needed for every exergy calculation. In practise, the first development of CEC provided a detailed and generally applicable reference system that remains the practical baseline for all exergy calculations based on CEC (Szargut, 2005). The framework determines the exergy value of a particular chemical compound compared to the standard chemical composition of the earth's bio- and lithosphere. Over time, this system has been updated (Szargut et al., 2005). It is a fixed environment independent of technical or operational assumptions. Contrary to comparisons of energy-based results, this exergy reference does not presuppose technical processes for energy transformation nor pathways of fuels production to which the process under investigation is compared, making calculations and comparison of results much more objective and robust.

\subsection{Solar irradiation to approximate ecosystem contributions}

For biobased processes, sunshine is essential in the biomass provision pathway. Hybrid biobased processes combine inputs of solar and fossil origin. A precise view on the balance between these two sources is crucial during the analysis of the sustainability of the process. For the purpose of sustainability assessments, some practitioners chose to partly omit the direct contribution of solar exergy for the biological organisms (Bastianoni et al., 2005), while others opt to totally omit the solar contributions (Hoang and Alauddin, 2011; Hoang and Rao, 2010; Illge et al., 2008; Van Passel et al., 2009). There are two approaches possible to include solar irradiation. A first approach is to include sunshine only indirectly, as represented by the biomass provided by the ecosystem to the industrial process (Sewalt et al., 2001). A more inclusive approach includes all solar irradiation directly, such as embedded in the CEENE methodology (Dewulf et al., 2007). This choice counts the total amount of solar exergy that was needed to produce the biomass, and extends thereby the horizon of the production chain to include the activity of the ecosystem that produces the biomass.

This extension opens the possibility to further broaden the horizon of the environmental impact analysis to the absorption of emitted pollutants by ecosystems. Three options are present in literature. Firstly, some projects account for the impact of pollution of ecosystems by counting the exergy content of the released pollutant itself (Gasparatos et al., 2009; Huang et al., 2007; Zhang and Chen, 2010). The exergy content of a pollutant is a measure of the thermodynamic work the pollutant can perform, and thus an approximate measure of the damage the pollutant can create when released in the biosphere. This approach is used for macro-economic assessments, but it is not very precise. A second approach is to include the activity of the ecosystem to absorb pollution, and is proposed by Dewulf and Van Langenhove (2002a). This method links exergy valuation of ecosystems with the 'Ecological Damage Effects' (EDE), a standardised environmental impact measure from LCA (Goedkoop et al., 1999). As such it provides a practical weight to aggregate pollution impacts from an LCA proportionally to the sunshine needed for the ecosystem to restore itself. Thirdly, when impact data from LCA are not available, it remains possible to calculate directly the 
solar irradiation necessary for the ecosystem to function. In case of sequestration, the pollutant is one of the input resources of the ecosystem, with a corresponding exergy cost. This approach is used in this article to estimate the exergy demand of carbon sequestration.

Annex A gathers an overview of articles that evaluate the production of bioenergy or biobased materials within a life cycle context. An overview of the applied methods is equally provided. It is remarkable that a majority of articles restrict the analysis of environmental impacts to the inclusion of renewable resources.

\subsection{Valuation of living organisms}

An advanced extension of the exergy theory concerns valuations of living organisms. This extension is proposed by Jørgensen (2002) as Eco-Exergy (EE). Standard exergy theory describes the exergy content of biological organisms as the chemical exergy of the dead matter that organisms contain. EE values the chemical content of living organisms together with their information content. The living organisms contain exergy not only through their chemical composition, but also through the information contained in its structure and form, more specifically expressed by the structure of its DNA. Based on the physical law of Boltzmann linking information theory and thermodynamics, EE combines both aspects (Jørgensen, 2007). The exergetic value of the information contained in living organisms often surpasses the chemical exergy content with several orders of magnitude (Fonseca et al., 2000). This approach has been elaborated as an indicator for ecosystems evolution and health (Jorgensen and Svirezhev, 2004; Jorgensen et al., 2004). The detailed EE approach is promising and might uncover missing links in current exergy LCA, such as ecosystem costs and contributions due to decreasing biodiversity. The current results are effectively applied as indicators for impacts on living organisms and their organisation (Jørgensen, 2006). This shows that this measure can be a useful indicator alongside other indicators of biodiversity and related environmental impact (Gontier et al., 2006). Currently it is not recommendable to combine EE with other exergy-based measures in calculations. The principle link between information theory and entropy has been criticised and remains debated (Corning and Kline, 1998a,b; Kline, 1999). The direct inclusion of EE in cumulative exergy analysis is not warranted because it departs from the pure thermodynamical measure, and the information measure of $\mathrm{EE}$, based on essential DNA strands, is debated among biologists (Silow and Mokry, 2010). It remains challenging to interpret these valuations of living ecosystems and organisms in relation with standard thermodynamical measurements, even if both are expressed in the same units.

\section{Limitations of exergy-based indicators}

As opposed to carbon or energy related measures, measures in exergy can extend the scope of the analysis to include energy, inorganic materials and fuels, organic matter, and even ecosystem activity related to the absorption of pollutants. This is an advantage over LCA because the environmental impacts can be aggregated over different dimensions. These advantages are unfortunately not sufficient to use exergy as a measure for all ecosystem services. Inclusion is limited to ecosystem services that concern material or energy flows. Other ecosystem services, such as noise reduction or cultural values, are immaterial, and can be objectively assessed neither with energy-, carbon- nor with exergy-based values.

\subsection{Application to immaterial resources}

The application of exergy terms to immaterial resources, such as temperature regulation, information exchange or cultural services, is similar to the inclusion of eco-exergy. Exergy is a fundamental thermodynamic measure for physical entities and exchanges, and is thus applicable to all material and energy flows. Immaterial resources have found parallel expressions in exergy, but as these measures depart from the thermodynamic basis, their inclusion is problematic. For instance, there are various attempts to express the two primordial economic resources, labour and capital, in terms of exergy (Sciubba, 2001, 2011; Ukidwe, 2005), but these approaches do not provide correct valuations in the context of a sustainability assessment as labour and capital values are immaterial and constituted of information.

\subsection{Loss of information after aggregation}

During the sustainability assessment, all inputs can be added up to one quantity measured in exergy. This total input is often the basis for efficiency measurements and scenario comparison. Whether the solar exergy is accounted for directly or indirectly, there is one consequence that requires a second indication. The inclusion of solar irradiation generates exergy flows that can be both renewable and non-renewable. The exergy value for both is the same, while the sustainability performance is different (Stougie and Van der Kooi, 2011). Methods that define sustainability on an exergy-basis only, differ in calculation principles, but they all include a clear distinction of exergy inputs between renewable and non-renewable sources (Dewulf et al., 2000; Lems et al., 2003; Sewalt et al., 2001). The renewable fraction of input (RF) is an important indicator for the sustainability of the process, because this information gets lost when the total exergy input is determined by adding all resources and impacts together. A correct interpretation needs to review both the total input and the renewable fraction in conjunction.

\subsection{Exergy as an ecocentric valuation}

Exergy measurements might be possible, but not appropriate for every type of productive resource. The use of exergy analysis is limited by the implicit value-assignation, as the choice for a biophysical metric is at the same time a value decision. A biophysical metric - and cumulative exergy content in particular - determines an ecocentric value for each flow (Gasparatos et al., 2008). Contrary to anthropocentric tools such as monetary or composite metrics, the biophysical metric is in principle more objective. It attributes a value to a product according to the exergy used up or 'invested' in the product during its production. This type of value is a 'cost of production' value, and is not applicable to all types of flows from an economic point of view. The alternative economic value assignment is based on utility. Utility incorporates the desirability of the product for a consumer and is as such independent of the cost and investments necessary to build the product. This alternative disregards the cost of production and determines the value on human behaviour based on choice and preferences.

Moreover, the energy cost of production theory has been shown to be inconsistent with market prices (Ayres, 2004). The theory is not applicable as a general economic theory because values determined by the energy cost of production rarely match values of the produced output. This is exactly because value determinations are governed not only by production costs alone but also by human preferences for goods or services, whenever interactions between humans are involved. An exergy cost of production, looks at flows and services from an ecocentric view, and is not influenced by human preferences for value determination (Raugei, 2011). Hence, this approach is not directly suitable for exchanges within the economy or with society, such as capital or labour. The situation is different for exchanges with ecosystems. There are no choices, decision or markets in an economic sense in the natural environment (Ayres, 2004), and thus no expression of preferences in order to determine different exchange values. For exchanges with ecosystems, the exergy cost is an appropriate and more objective measure (Valero, 2006). For other exchanges, involving human preferences and choices, other solutions have to be found. 


\subsection{Output valuation}

The economic interpretation of exergy values has effects not only on the valuation of process inputs, but also on the valuation of the outputs. In most research projects using exergy analysis, the output is valued in net exergy content (Apaiah et al., 2006; Chen et al., 2009; Hepbasli, 2008; Kaushik et al., 2011; Talens Peiró et al., 2010; Zhu et al., 2005). According to the economic interpretation of exergy content, this approach views both inputs and outputs from an ecocentric point of view. It looks at the process under investigation as a matter- and energy-transforming unit within the biosphere.

The alternative is to value the output in monetary terms, which corresponds to the anthropocentric valuation of the output. This second approach acknowledges the fact that some outputs are more valuable for humans than others, and that the output ultimately achieves its value through interaction with customers. Both approaches are valid and appropriate if all outputs are materials or energy flows. The underlying premises should be taken into account during the interpretation of the results. In order to illustrate this difference, the application in the case study compares both interpretations of output.

\section{Framework to assess sustainability of biobased products and bioenergy}

Exergy accounting can value material and energy inputs in an objective way by determining their exergy cost of production. Ecosystem activity to absorb pollutants or to provide organic matter can also be quantified similarly. And exergy is not suitable for the valuation of immaterial exchanges, information, or exchanges that are determined by human interactions and preferences. Inclusive sustainability assessments should incorporate many different aspects, and should provide solutions to aggregate impacts measured in exergy with other impacts. The first section of this chapter builds a framework, allowing all relevant aspects and impacts to be categorised and measured. The second section looks at existing composite indicators with exergy, and determines options for aggregation in this case.

\subsection{Impact structure for an inclusive sustainability assessment}

In a first step, impacts are structured according to (i) the nature of the exchange, and (ii) the origin or destination of the exchange. Berkes and Folke (1994) distinguish three kinds of exchanges between an economic process and ecosystems: non-renewable resources extracted from ecosystems, renewable resources produced and maintained by ecosystems, and environmental services. Distinctions in our framework are then detailed as follows:

- Non-renewable resources: these are resources that are not regenerated during the period of the project under investigation. In this case, the assessment looks at the influence of an economic process during its lifetime (e.g. 25 to 30 years). Non-renewable resources include all fossil fuels and minerals, geological mineral deposits and fossil water reserves. It also includes organic matter from biological systems that take longer than the project lifetime to grow or impacts on ecosystems that require the ecosystems longer than the project lifetime to recover.

- Renewable resources: these are resources that are actively regenerated by ecosystems or other systems (e.g. lithosphere). These include grown organic matter or geothermal heat.

- Services: Services are exchanges with the process that are not based on matter or energy exchange. For interactions with ecosystems, the term ecosystem services cover a large variety of meanings and interactions (Fisher et al., 2009). This is a much more limited definition, as for instance the provision of rainwater to the economic process is not an ecosystem service. Rainwater is considered a material resource. Ecosystem services that remain under this restricted category are for instance pollination by bees or cultural and touristic qualities of the landscape that are used by the economic process.

Impacts are also structured according to the origin or destination of the exchange: society, the biosphere and the economy as shown in Fig. 1. Other projects similarly distinguish flow origins in principle areas (Dewulf and Van Langenhove, 2002b; Dewulf et al., 2007; Simpson and Edwards, 2011). This resembles the representation of the economic process according to ecological economics (Gowdy and Erickson, 2005). In Fig. 1, the different flows are visualised combining the distinction according to the nature of exchange and the origin. The impacts of the economic process in Table 1 present a large diversity. This diversity is often sufficient for regular sustainability assessments for biomass and bioenergy projects. CEC and CEENE can account for all exchanges of materials and energy flows to and from the economic process, including organic materials.

Damages caused by pollutants and emissions can both be material and immaterial. The material effects of pollution absorption by the biosphere can be assessed by counting the biomass loss caused by the pollution, and can be measured in exergy terms. The immaterial aspects, such as structural degradation or biodiversity reduction cannot be analysed in classical exergy metrics. It should be treated as an environmental impact assessment in an alternative metric. Also all exchanges with society, as well as all immaterial services should be accounted for in different metrics or dimensions.

\subsection{Measure determination and aggregation across different dimensions}

With an extended view over the production chain and the diversity of impacts accounted for, the exergy measurements do not suffice. It is remarkable that most methods for the assessment of agricultural sustainability (Acosta-Alba and Van der Werf, 2011; van der Werf et al., 2007; Van Passel and Meul, 2011), fall within the category of composite indicators. The sustainability analysis touches upon very diverse range of aspects that cannot be aggregated without having to turn to composite metrics in the end. Exergy-based measures aggregate different forms of energy, materials, or pollution abatement on a standard physical basis, which is an important advantage. However, exergy-based measures cannot avoid the use of aggregating and weighing altogether.

Exergy-based measures are only rarely applied in combination with other indicators. The early development of the exergy cost method led to the combination of exergetic and economic costs. The resulting field of exergoeconomics or thermoeconomics has been fruitful for the design of complex energy systems and is still in evolution (Kim, 2010; Kim et al., 1998; Rosen, 2008; Tsatsaronis, 2006; Tsatsaronis and Pisa, 1994; Valero et al., 1994). It remains for a large part focused on cost allocation, and design optimisation of energy producing plants (Abusoglu and Kanoglu, 2009). This approach compares exergy investments with economic costs and benefits of the process. This approach does not see economic costs as a valuation method for impacts that cannot be assessed by exergy, and as such the approach does not combine the measured impacts in two different metrics. It rather provides a ratio between efficiency in exergy terms and economic benefit. Focussing more on environmental impacts, Verdesca et al. (2006) combine exergy-based values and economic added values for the appraisal of the ecosystem contribution to the economy. Yi et al. (2004) equally derive economic-environmental ratios to evaluate the exergy-use during the life cycle of an industrial process. But strictly speaking, these applications do not combine two impacts in two different dimensions to complete an inclusive sustainability assessment.

In order to combine impacts measured in different dimensions into a single composite indicator, various methods for aggregation are available (Nardo et al., 2005; Wang et al., 2009). Most often, the different dimensions are combined in indicators by means of weights and ratios. These weights can be determined through an overall ideal vision of 


\begin{tabular}{|c|c|c|c|c|c|}
\hline & & \multicolumn{3}{|c|}{ From \& to } & \multirow[b]{2}{*}{ Society } \\
\hline \multirow{3}{*}{$\begin{array}{l}\text { Can be accounted } \\
\text { for in } \\
\text { exergy terms }\end{array}$} & & Biosphere & Lithosphere & Sun & \\
\hline & $\begin{array}{l}\text { Non- } \\
\text { renewable } \\
\text { resources }\end{array}$ & $\begin{array}{l}\text { Diverse ecosystem contributions: materials, } \\
\text { Ecosystem damage due to waste absorption or } \\
\text { emission capture and storage... }\end{array}$ & $\begin{array}{l}\text { Minerals, Fossil fuels, } \\
\text { Historic water reserves, } \\
\text { Waste storage }\end{array}$ & & \\
\hline & $\begin{array}{l}\text { Renewable } \\
\text { resources }\end{array}$ & $\begin{array}{l}\text { Diverse ecosystem contributions: materials, rain, } \\
\text { wind, Ecosystem adaptation and regeneration due to } \\
\text { waste absorption or emission sequestration... }\end{array}$ & Geothermal heat, Water & $\begin{array}{l}\text { Solar } \\
\text { irradiation }\end{array}$ & \\
\hline $\begin{array}{l}\text { Cannot be } \\
\text { accounted for in } \\
\text { exergy terms }\end{array}$ & Services & $\begin{array}{l}\text { Soil fertility, Pollination, Noise reduction, Genetic } \\
\text { information, Biodiversity, Touristic Qualities }\end{array}$ & Land use & & $\begin{array}{l}\text { Labour, } \\
\text { Capital }\end{array}$ \\
\hline
\end{tabular}

Fig. 1. An overview of inputs for the economic process shows the potential broad application of exergy as a metric for environmental impacts.

sustainability, aligned to policy decisions, or through discussion with experts and the community involved. The advantages of weighing are surely the large flexibility and capacity for adaptation to local circumstances. It creates instruments that are able to combine aspects of a very different nature into one indicator. It increases clarity for discussions, but it should be noted that these weightings often lack theoretical underpinning and can be regarded as subjective.

There are other approaches possible, based on multi-criteria analysis or efficiency measurements. The choice of aggregation method depends inherently of the practical case at hand. The next section illustrates the set-up of a combined sustainability assessment that makes use of exergy-based indicators for many of the environmental impacts, and that uses a standard economic frontier methodology to aggregate these impacts with measures in different dimensions.

\section{Practical illustration}

The illustration is based on a large industrial greenhouse for the production of bell peppers in Belgium. This industrial production process combines a technical process, regulating the heat and internal atmosphere in the greenhouses, and a biological process of bell pepper production. The production depends on multiple contributions from the sun, from surrounding ecosystems, from the lithosphere and from the economy. Currently, the greenhouses are heated by a group of cogeneration units. Exhaust fumes from the cogenerations are cleansed and injected in the greenhouse to increase the air's $\mathrm{CO}_{2}$-content.

\subsection{Scenarios and methodology construction}

Five scenarios for alternative heating techniques are investigated: a traditional gas-fired boiler, a new cogeneration park, geothermal heat supplemented with a heat pump, geothermal heat supplemented with a small cogeneration unit, and a cogeneration unit fired with biodiesel from rapeseed. Every scenario has been evaluated with three different concentrations of $\mathrm{CO}_{2}$ in the greenhouse air: without $\mathrm{CO}_{2}$-injection; with $1.000 \mathrm{ppm} \mathrm{CO}$ and with a maximum content of $1.500 \mathrm{ppm} \mathrm{CO}_{2}$. Production of bellpeppers yields about 170 ton/ha with atmospheric air composition in the greenhouse. An increase to $1.000 \mathrm{ppm} \mathrm{CO}_{2}$ improves the production to about 227 ton/ha and an increase to $1.500 \mathrm{ppm} \mathrm{CO}$ can lift the production to 300 ton/ha (Bencze et al., 2011; Rezende et al., 2003; Tremblay and Gosselin, 1998). The type of heating installation determines the availability of the $\mathrm{CO}_{2}$ for the greenhouse. The greenhouse air composition determines the growth performance, but equally the use of chemicals, fertiliser needs, and the use of ecosystem resources, labour needs and capital. The summary of all elements taken into account for the sustainability analysis is illustrated in Fig. 2.

Table 1

The results indicate significant differences between the ecocentric and anthropocentric views.

\begin{tabular}{|c|c|c|c|c|c|c|c|c|c|c|}
\hline & \multirow[t]{2}{*}{ Technical process } & \multirow[t]{2}{*}{ Greenhouse atmosphere $\mathrm{CO}_{2}$ augmentation } & \multirow[t]{2}{*}{ Produced outputs } & \multirow[t]{2}{*}{$\mathrm{RF}$} & \multicolumn{3}{|c|}{$\begin{array}{l}\text { Ecocentric output } \\
\text { valuation }\end{array}$} & \multicolumn{3}{|c|}{$\begin{array}{l}\text { Anthropocentric output } \\
\text { valuation }\end{array}$} \\
\hline & & & & & $\theta$ & $\mathrm{AE}$ & SE & $\theta$ & $\mathrm{AE}$ & SE \\
\hline 1 & Boiler on natural gas & $1500 \mathrm{ppm}$ & Bell peppers & $18 \%$ & $26 \%$ & $98 \%$ & $25 \%$ & $100 \%$ & $34 \%$ & $34 \%$ \\
\hline 2 & Boiler on natural gas & $1000 \mathrm{ppm}$ & Bell peppers & $18 \%$ & $21 \%$ & $99 \%$ & $21 \%$ & $77 \%$ & $33 \%$ & $25 \%$ \\
\hline 3 & Boiler on natural gas & No & Bell peppers & $19 \%$ & $17 \%$ & $100 \%$ & $17 \%$ & $59 \%$ & $33 \%$ & $19 \%$ \\
\hline 4 & Cogeneration & $1500 \mathrm{ppm}$ & Bell peppers and electricity & $17 \%$ & $100 \%$ & $100 \%$ & $100 \%$ & $100 \%$ & $31 \%$ & $31 \%$ \\
\hline 5 & Cogeneration & $1000 \mathrm{ppm}$ & Bell peppers and electricity & $17 \%$ & $100 \%$ & $97 \%$ & $97 \%$ & $100 \%$ & $26 \%$ & $26 \%$ \\
\hline 6 & Cogeneration & No & Bell peppers and electricity & $17 \%$ & $100 \%$ & $96 \%$ & $96 \%$ & $100 \%$ & $22 \%$ & $22 \%$ \\
\hline 7 & Geothermal \& Heat pump & $1500 \mathrm{ppm}$ & Bell peppers & $53 \%$ & $94 \%$ & $79 \%$ & $74 \%$ & $100 \%$ & $100 \%$ & $100 \%$ \\
\hline 8 & Geothermal \& Heat pump & $1000 \mathrm{ppm}$ & Bell peppers & $51 \%$ & $81 \%$ & $78 \%$ & $63 \%$ & $91 \%$ & $86 \%$ & $78 \%$ \\
\hline 9 & Geothermal \& Heat pump & No & Bell peppers & $49 \%$ & $78 \%$ & $72 \%$ & $55 \%$ & $100 \%$ & $62 \%$ & $62 \%$ \\
\hline 10 & Geothermal \& Cogeneration & 1500 ppm & Bell peppers and electricity & $38 \%$ & $97 \%$ & $83 \%$ & $81 \%$ & $100 \%$ & $75 \%$ & $75 \%$ \\
\hline 11 & Geothermal \& Cogeneration & $1000 \mathrm{ppm}$ & Bell peppers and electricity & $38 \%$ & $100 \%$ & $73 \%$ & $73 \%$ & $100 \%$ & $58 \%$ & $58 \%$ \\
\hline 12 & Geothermal \& cogeneration & No & Bell peppers and electricity & $38 \%$ & $85 \%$ & $77 \%$ & $66 \%$ & $85 \%$ & $52 \%$ & $45 \%$ \\
\hline 13 & Cogeneration on bioethanol & 1500 ppm & Bell peppers and electricity & $79 \%$ & $100 \%$ & $73 \%$ & $73 \%$ & $100 \%$ & $22 \%$ & $22 \%$ \\
\hline 14 & Cogeneration on bioethanol & $1000 \mathrm{ppm}$ & Bell peppers and electricity & $79 \%$ & $100 \%$ & $71 \%$ & $71 \%$ & $98 \%$ & $19 \%$ & $19 \%$ \\
\hline 15 & Cogeneration on bioethanol & No & Bell peppers and electricity & $79 \%$ & $100 \%$ & $70 \%$ & $70 \%$ & $100 \%$ & $16 \%$ & $16 \%$ \\
\hline
\end{tabular}

For each valuation type, the bold figures indicate the most efficient scenario to which all other scenarios are compared.

RF: Renewable Exergy fraction [\%].

$\theta$ : Production efficiency [\%].

AE: Allocative Efficiency [\%].

SE: Sustainability Efficiency [\%], SE $=\theta \times \mathrm{AE}$. 


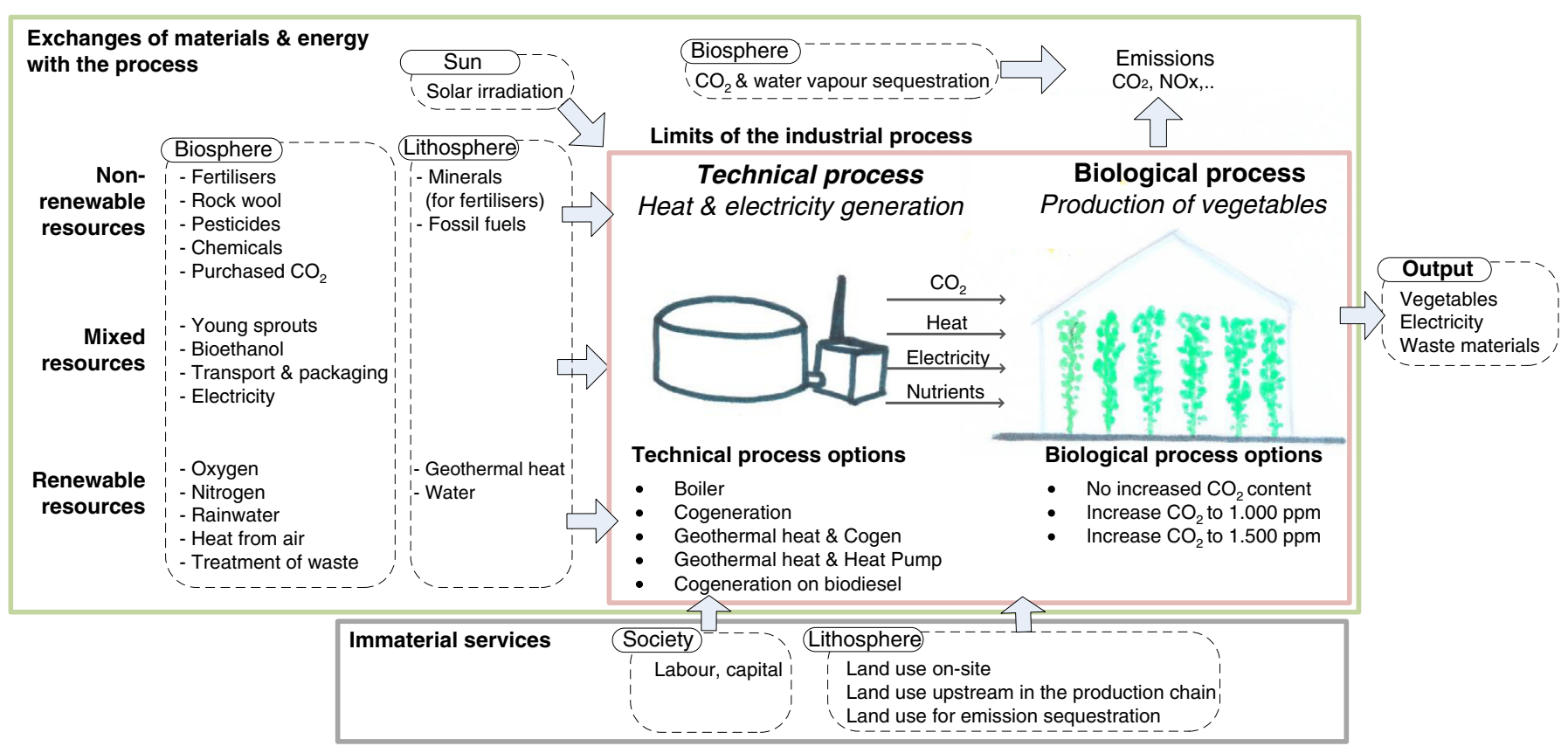

Fig. 2. The variety of quantified flows of resources and services taken into account for the case-study makes a composite sustainability indicator necessary.

An inclusive sustainability assessment methodology for this situation can partly be based on exergy-indicators. The sum of impacts accounted for in exergy covers all renewable and non-renewable inputs. The remaining aspects, services exchanged with society and land use, are divided in three components: land use, labour and capital. The total of four categories is aggregated with frontier analysis.

Standard frontier methods, such as data envelopment analysis (DEA) or stochastic frontier analysis (SF) are readily being applied to combine measurements into one single indicator (Nardo et al., 2005). Standard production frontier analysis determines the processes within a group that use all resources most efficiently. These maximally efficient processes constitute together the efficiency frontier. The processes on the frontier utilise all resources combined as efficiently as possible. Other processes are enclosed by the frontier and perform less efficiently. The further the process is located from the frontier, the less efficient it is. This defines an overall economic efficiency $\theta$ for each process. A process that is on the efficiency frontier has $\theta$ equal to $100 \%$. Hoang and Rao (2010) combine this approach with a minimisation of the Cumulative Exergy Content of the productive inputs. After determination of the overall economic efficiency $\theta$ for each process $\mathrm{k}$, Hoang and Rao (2010) determine the particular process on the frontier that has the minimal cumulative exergy input per unit output. The most sustainable production process thus achieves a maximally efficient resource use on the frontier and at the same time a minimal CEC per unit output. This leads to the additional definition of the allocative efficiency (AE) of each process. This AE describes the reduction in CEC input use that the process can obtain by moving along the efficiency frontier. This movement represents not an overall efficiency gain, but a modification in the allocation between the different input resources while keeping the overall production efficiency the same. The combination of $\theta$ resulting from standard economic efficiency analysis and $\mathrm{AE}$ resulting from $C E C$ minimisation determines the most sustainable process. The formulas for the determination of both variables are given in annex $\mathrm{C}$.

Fig. 3 summarizes the resulting indicator framework in an 'information pyramid' adapted from Hammond et al. (1995). Quantification starts from the primary data. These are transformed and aggregated into analysed data. The renewable fraction of the exergy input, denoted by indicator RF, remains essential for the description of sustainability of the process, as it contains information that is not available in the final index. This set-up summarizes the use of exergy-based measures of environmental impacts in a sustainability assessment. This approach is able to include multiple environmental impacts in the same objective units, and combines it with aspects that cannot be assessed in any biophysical measure. In principle, it gives a much more holistic result than energy-related sustainability measures for bioenergy projects.

Most ecosystem resources and related ecosystem adaptations can be quantified through the CEENE approach. Two aspects still need

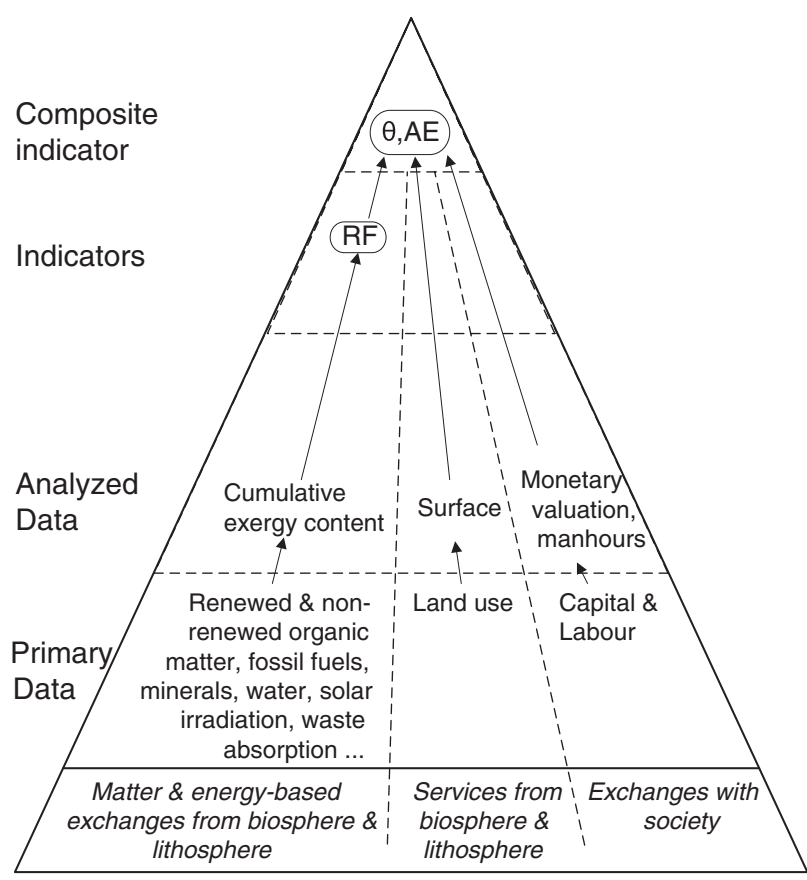

Fig. 3. The 'Information pyramid' for the final structure of environmental sustainability indicators.

Adapted from Hammond et al. (1995). 
clarification, the sequestration of emitted $\mathrm{CO}_{2}$ and the production of oxygen. Some industrial processes sequester carbon, and the related exergy costs have been calculated. Valero and Botero (2002) report exergy abatement costs for emissions from electricity plants ranging between 1.27 and $2.04 \mathrm{MJ} / \mathrm{kg} \mathrm{CO}_{2}$. These exclude the disposal of the liquefied gas. Dewulf and Van Langenhove (2002a) report an abatement cost of $5.86 \mathrm{MJ} / \mathrm{kg}$, for a similar process, including underground storage of the emissions. These are abatement technologies in industrial applications based on non-renewable exergy inputs. For an abatement cost based on renewable exergy inputs, estimation is made for the abatement cost of $\mathrm{CO}_{2}$ through forest growth in Appendix $\mathrm{B}$. This estimation is very rudimentary and primarily shows that further research is required to detail this aspect in exergy-based life cycles.

\subsection{Results}

To illustrate the divergence in the use of exergy-based indicators, the results based on calculations with various assumptions are compared. The renewable fraction (RF) of all input resources is calculated by adding all sunlight used in the production of renewable resources, for the activity of forests to sequester emitted $\mathrm{CO}_{2}$ and to produce oxygen, and for the sunlight captured by the greenhouses and the bell pepper plants. The calculations of abatement costs for $\mathrm{CO}_{2}$ are presented in Appendix B.

Table 1 gathers the list of investigated scenarios and their results. The calculation is performed twice, once for the output valued in exergy terms (the ecocentric approach), and once for the output valued in monetary terms (the anthropocentric approach). There is a large difference between these two valuation principles. Table 2 shows different prices per GJ actual exergy content of different substances drawn from the case study. A monetary valuation of the outputs establishes a much higher value for heat flows than for electricity for instance. Also the production of fertilisers is much more valuable to society than the exergy content would attribute to it. The distinction between these two approaches becomes increasingly important as innovative renewable energy and biomass projects often produce fertiliser replacements and livestock fodder, in addition to traditional outputs such as electricity or heat. Especially these biobased by-products present significant valuation differences. It is therefore all the more important to denote clearly the choice made when evaluating innovative bioenergy projects.

With an ecocentric output valuation, the scenarios producing both bellpeppers and electricity show the best results. In exergy terms, electricity is valued much higher than bell peppers. The most sustainable scenario is in this case scenario 4, with a large cogeneration based on natural gas and $\mathrm{CO}_{2}$-sequestration in sustainably managed forests. It is surprising that scenario 13 , with a cogeneration of equal size fuelled with biodiesel, is less sustainable. The case-study is based on a particular pathway, an inefficient rapeseed biodiesel production, requiring large land surfaces and large quantities of sunlight.

Using anthropocentric output valuation, the outputs are valued based on market prices. This reflects closer the value of the outputs in

Table 2

The actual price per GJ exergy differs largely according to the output.

\begin{tabular}{ll}
\hline Substance & Price per unit net exergy content \\
\cline { 2 - 2 } & {$[€ / \mathrm{GJex}]$} \\
\hline Waste wood & 3.5 \\
Natural gas & $8.2-9.2$ \\
Electricity & 17 \\
Ureum & 21 \\
Low temperature heat & 42 \\
Fertiliser & 602 \\
Bellpeppers & 440 \\
Young sprouts & 10.402 \\
\hline
\end{tabular}

society, contrary to their value in the biosphere when valued in exergy, and it leads to entirely different results. In this case the scenarios based on geothermal heat are preferred. The other scenarios have a large disadvantage and do not obtain sustainability indicators higher than $35 \%$. Again the inefficient biodiesel provision pathway puts the overall performance of the biomass scenarios lower than the cogeneration based on natural gas.

\section{Conclusions}

Sustainability assessments based on carbon or energy accounting, face difficulties to assess complex and innovative productions of bioenergy and biobased materials. These projects show a growing complexity and produce regularly material flows simultaneous with energy flows. Moreover, a large variety of environmental impacts can be observed. Energy and $\mathrm{CO}_{2}$-centred methods are limited to take into account all relevant aspects.

Because of its thermodynamic basis, exergy can be more appropriate to measure various aspects. An increasing use of exergy indicators to analyse bioenergy and biomass projects can be observed in literature. The major advantage is that the calculation methods are capable of estimating various environmental impacts on the same basis. Moreover, the solar irradiation, used by the ecosystem to provide the ecosystem resources, can equally be integrated in this manner. The wide range of applications of exergy measures for environmental impact assessment and sustainability analysis demonstrates the usefulness and potential of this approach. There is some degree of standardisation in exergy measurement. Publications mainly use the same calculation principles and reference frameworks, which reinforces the general acceptation of these calculations. But practical applications show divergent uses of exergy indicators.

At the moment, there is no generally accepted framework that distinguishes the impacts that can be valued in exergy terms. There are diverging views on the inclusion of labour, capital, sunlight or living organisms. However looking at the economic interpretation of exergy valuation (Gasparatos et al., 2008), it can be principally derived that any aspect that is determined by human preference or choice should be excluded. From a thermodynamic point of view, exergy is not the optimal choice either to deal with immaterial exchanges. It is advisable to restrict the use of exergy-based measures to the material and energy exchanges with the sun, the biosphere and lithosphere. This practical restriction implies that the other aspects need to be accounted for with other measurement methods in other dimensions. An inclusive sustainability assessment will need to combine these different measurement and will be based on aggregation of indicators of different dimensions. Exergy can reduce the combination of different dimensions drastically by counting all different exchanges on the same basis. But a complete reduction into a single measure cannot be realised.

Unfortunately, very few examples exist where exergy-based measures are combined with measurements in different metrics to form a composite sustainability indicator. Aggregation provides most benefit if the ecocentric interpretation of exergy is respected. Other calculations provide the impacts valued from an anthropocentric point of view. Within an aggregated indicator set, both of these perspectives can be respected and the results present a more inclusive and sound analysis of the sustainability of renewable energy and biomass projects, especially compared to standard energy- or carbon-based indicators.

Different options remain for the construction of an aggregated indicators set. The valuation of the output can be decided according to the situation. Most projects that develop exergy-based indicators value the output equally in exergy. But this implicitly assumes that value is defined ecocentrically and it strongly influences the results of the sustainability assessment. From a social perspective, it is recommended to value outputs in monetary terms. These represent the anthropocentric value much closer. These results favour biobased materials over bioelectricity for instance, where an ecocentric 
interpretations yields the opposite result. Fundamentally, both valuation methods are valid, but the choice of perspective should be considered during the interpretation of the results.

There are many facets of this approach that can benefit from further research. The actual cost of $\mathrm{CO}_{2}$-sequestration by renewable sources remains an important question. But also the determination of more precise and differentiated ecosystem exergy contents, depending on biological characteristics of the ecosystem, can provide valuable additions. At present, the integration of exergy accounting in aggregated sustainability assessments is relatively rare. Future applications of this approach in different situations are required to clarify precisely the potential of exergy-based indicators in a sustainability context.

\section{Acknowledgments}

The authors would especially like to thank Charalabos Pouliakis for the excellent data collection. Remarks from Dr. Nele Witters and two reviewers strongly improved the paper. This project has been financed by the Impuls-project of the Transnational University Limburg (TUL, Belgium and the Netherlands).

\section{Appendix A}

Table 3 gives an overview of papers investigating the production of bioenergy and biobased materials from a life cycle perspective with exergy-based indicators. The following different methodologies are used in the papers:

CEC The standard method to utilise exergy within a life cycle context is the calculation of the Cumulative Exergy Content (CEC) (Szargut et al., 1988). The CEC accounts for the cumulative quantity of exergy being destroyed or used during the life cycle of a product. The CEC can account for mineral resources and fossil inputs in production processes.
CEENE The Cumulative Exergy Extraction from the Natural Environment (CEENE) further extends the CEC to include also resources extracted from renewable sources and ecosystems (Dewulf et al., 2007). CEENE includes renewable matter by first counting the total solar exergy on the land that was needed to produce the resource. Then $2 \%$ of this total irradiation is included in the total exergy accumulation of the product. This percentage represents the maximum metabolic efficiency of the natural organisms. Algae have shown to transform solar exergy into biomass with an efficiency of about $2 \%$. Higher efficiencies are only reported for species in ideal labconditions or engineered organisms (Melis, 2009; Zhu et al., 2008). As such CEENE values the biomass production as if the natural environment produced biomass with maximum efficiency. If the actual ecosystem produces the renewable resources less efficiently, the ecosystem will require more land and more solar irradiation, and this will have a corresponding impact on the overall result.

EEA Extended exergy accounting (EEA) is based on CEC and includes two factors representing the needs for capital and labour (Sciubba, 2001). Both are defined on a macroeconomic basis and form a ratio between labour or capital and the exergy needed to provide this service (Sciubba, 2011). These extensions express all productive factors that are usually regarded in economic analysis in exergetic terms. EEA shows then an exergetic parallel view of the economic analysis.

ECEC Even with all the different extensions and evolutions of exergy theory, one point of concern remains the correct inclusion of the work of ecosystems in the overall lifecycle of a product. CEENE has made a step to integrate renewable resources, but other ecosystem services are still hard to account for. Ecological Cumulative Exergy Consumption (ECEC) proposes to make a link between exergy analysis and the knowledge of ecological processes gained through Emergy analysis (Hau and Bakshi, 2003). Emergy is a different physical metric, and is defined as "the availability of energy of one kind that is used up in transformations directly and indirectly

Table 3

Papers investigating the production of bioenergy and biobased production from a life cycle perspective with exergy-based indicators.

\begin{tabular}{|c|c|c|c|}
\hline Paper & Type of bioenergy or biobased product & Method & Particularities \\
\hline Dewulf et al. (2000) & Bio-ethanol from wheat grain & CEC & $\begin{array}{l}\text { Sustainability assessed with renewability and efficiency indicators. } \\
\text { Extended CEC with inclusion of solar irradiation. }\end{array}$ \\
\hline Dewulf et al. (2005) & Biodiesel production & CEC & Comparison of three production pathways \\
\hline $\begin{array}{l}\text { Brehmer et al. } \\
\text { (2008) }\end{array}$ & Comparison of different legumes as biorefinery feedstock & CEC & The paper describes the efficiency of the legume production \\
\hline Yang et al. (2009) & Corn-based ethanol & CEC & Cradle-to-gate analysis without environmental effects \\
\hline $\begin{array}{l}\text { Urban and Bakshi } \\
\text { (2009) }\end{array}$ & 1,3-Propanediol from fossil and from renewable sources & CEC and ECEC & $\begin{array}{l}\text { Comparison of different methods to see the effect of included ecosystem } \\
\text { services }\end{array}$ \\
\hline $\begin{array}{l}\text { Baral and Bakshi } \\
\text { (2010) }\end{array}$ & Comparison of different transport fuels & ECEC & \\
\hline Buchgeister (2010) & $\begin{array}{l}\text { Electricity production using a solid oxide fuel cell with } \\
\text { biomass gasification }\end{array}$ & Exergy and LCA & $\begin{array}{l}\text { Exergy-based analysis, but not over the entire life cycle. Life cycle impacts } \\
\text { are distributed pro rata of exergy contents }\end{array}$ \\
\hline $\begin{array}{l}\text { Talens Peiró et al. } \\
\text { (2010) }\end{array}$ & Biodiesel production & EEA & Comparison of two production pathways \\
\hline $\begin{array}{l}\text { Banerjee and Tierney } \\
\text { (2011) }\end{array}$ & Biomass boiler for heat & CEC and EEA & Comparison with other technologies \\
\hline $\begin{array}{l}\text { De Meester et al. } \\
\text { (2011) }\end{array}$ & $\begin{array}{l}\text { Comparison of biorefinery scenarios for the production of } \\
\text { food, biobased products and bioenergy }\end{array}$ & CEENE & Cradle-to-gate analysis including environmental impacts. \\
\hline Liao et al. (2011) & Bioethanol from corn & $\begin{array}{l}\text { Combined CEENE, } \\
\text { CEC and EEA }\end{array}$ & Combined methodology \\
\hline $\begin{array}{l}\text { Özilgen and } \\
\text { Sorgüven (2011) }\end{array}$ & Vegetable olive, sunflower and soybean oil production & CEC & $\begin{array}{l}\text { Thorough cradle-to-gate life cycle view. No integration of emissions or } \\
\text { sunlight }\end{array}$ \\
\hline $\begin{array}{l}\text { Rubio Rodríguez } \\
\text { et al. (2011) }\end{array}$ & Different transport fuels & $\begin{array}{l}\text { Combined CEC, EEA } \\
\text { and CEENE }\end{array}$ & Combined methodology \\
\hline $\begin{array}{l}\text { Christopher and } \\
\text { Dimitrios (2012) }\end{array}$ & Comparison of renewable pathways of hydrogen production & CEC & $\begin{array}{l}\text { Life cycle view from cradle to gate, does not include environmental } \\
\text { impacts }\end{array}$ \\
\hline $\begin{array}{l}\text { De Meester et al. } \\
\text { (2012) }\end{array}$ & Anaerobic digestion for heat and electricity production & CEENE & Cradle-to-gate analysis including environmental effects and sunlight \\
\hline $\begin{array}{l}\text { Neupane et al. } \\
\text { (2013) }\end{array}$ & Wood-derived ethanol & ECEC & \\
\hline $\begin{array}{l}\text { Taelman et al. } \\
\text { (2013) }\end{array}$ & Algae for aquaculture feedstock & CEENE & Includes scenarios for increased efficiency \\
\hline
\end{tabular}


to make a product or service" (Odum et al., 2000). Emergy analysis traces back solar energy expenditure during the entire life cycle of the object under investigation, and includes essential contributions from ecosystems and the earth's crust (Odum, 1996). It has been applied to estimate the energy density of renewable fuels, wind, rain, volcanic heat, waves and tidal energy to name but a few (Brown and Bardi, 2001; Odum, 1996). However, the theory has also been extended to evaluate the value of money or human labour. This and other aspects of Emergy analysis have been controversial and did limit the integration of Emergy analysis in other domains (Hau and Bakshi, 2004).

The ECEC approach makes use of the transformaties in Emergy analysis in a CEC calculation and avoids thus more controversial parts of Emergy literature such as the link with money or the Maximal Empower principle. But Emergy analysis has been evaluated not to be consistent with the second law of thermodynamics, especially when accounting for heat transfer (Sciubba, 2010). Whereas direct integration of emergy results in exergy calculations is often proposed (Bastianoni et al., 2007; Hau and Bakshi, 2003), this difference in approach makes this integration untenable. But even when the integration in an exergy-based analysis should be done cautiously, this does not reduce the merit of Emergy analysis as such (Jorgensen and Svirezhev, 2004; Sciubba, 2010).

\section{Appendix B}

Natural processes sequester $\mathrm{CO}_{2}$ by building up natural carbon reserves. The energy needed for the sequestration of $\mathrm{CO}_{2}$ could be estimated. A crude estimation of this exergy cost per unit $\mathrm{CO}_{2}$ can be done based on the chemical equation for organic matter (Jorgensen and Svirezhev, 2004).

$$
3.500 \mathrm{CO}_{2}+2.700 \mathrm{H}_{2} \mathrm{O}+600 \mathrm{HNO}_{3} \leftrightarrow \mathrm{C}_{3.500} \mathrm{H}_{6.000} \mathrm{O}_{3000} \mathrm{~N}_{600}+4.250 \mathrm{O}_{2}
$$

Detailed long term measurements of inputs and outputs of forests yielded indications for all flows in this equation. The sequestration is fuelled by solar exergy. But most of this exergy is used up for the evaporation of water. An overview of the inputs and outputs of forest area are given in Table 4. These flows are based on measurements reported by Berbigier et al. (2001).

The total amount of exergy in the inputs is attributed to the outputs pro rata of their intrinsic exergy content. This defines the total exergy cost for every output separately (Valero et al., 1986). The exergy cost for sequestering $\mathrm{CO}_{2}$ with the biological process in a natural forest is estimated at about $100 \mathrm{MJ} / \mathrm{kg} \mathrm{CO}_{2}$. When comparing this solar exergy to fossil exergy costs, only $2 \%$ is accounted for, which gives an equivalent of roughly $2 \mathrm{MJ} / \mathrm{kg} \mathrm{CO}$ in fossil terms. This is comparable to the sequestration costs reported with industrial processes. Another input of the economic process is oxygen. The production cost of oxygen turns out to be about $1.1 \mathrm{MJ} / \mathrm{kg}$. This is a "cumulative exergy cost" of oxygen that is approximately nine times the net exergy content of oxygen as defined by the CEC method.

\section{Appendix C}

The production efficiency analysis chosen in this case is the Data Envelopment Analysis (DEA). The DEA is defined for $K$ firms, each producing a vector $\mathbf{y}$ of $M$ outputs, $\boldsymbol{y} \in \boldsymbol{R}_{+}^{M}$ requiring an input vector $\mathbf{x}$ of $N$ inputs, $\boldsymbol{x} \in \boldsymbol{R}_{+}^{N}$. For the $k$ th firm, $1 \leq k \leq K$, the output and input vectors are defined as:

$\boldsymbol{y}^{k}=\left[y_{1}^{k}, . ., y_{m}^{k}, . ., y_{M}^{k}\right]^{T} ; 1 \leq m \leq M$

$\boldsymbol{x}^{k}=\left[x_{1}^{k}, . ., x_{n}^{k}, . ., x_{N}^{k}\right]^{T} ; 1 \leq n \leq N$.

The total output and input matrices are defined as:

$Y=\left[y^{1}\left|\ldots y^{k}\right| \ldots y^{K}\right] ; Y \in R_{+}^{M x K} X=\left[x^{1}\left|\ldots x^{k}\right| \ldots x^{K}\right] ; X \in R_{+}^{N x K}$.

For each firm a minimal scalar $\theta^{k}$ is derived that satisfies:

$$
\begin{gathered}
\min _{\theta, \lambda} \theta^{k}, \\
y^{k} \leq \lambda * Y ; \\
\theta^{k} \cdot x^{k} \geq \lambda * X ; \\
\lambda \geq 0 ; \\
\lambda \in R_{+}^{K x 1} .
\end{gathered}
$$

This definition is the envelopment form of DEA, as outlined by Coelli et al. (2005). This algorithm seeks the minimal linearly reduced input for firm $k$ that can produce the same output as firm $k$. If a linear combination of all firms in the set $K$ can produce $y^{k}$, for only the fraction of inputs $\theta^{k} x^{k}$, then $\theta^{k}$ indicates the Production Efficiency (PE) of the $k$ th firm.

According to the definitions of Hoang and Rao (2010) the indicators for the sustainable efficiency (SE) and its components are as follows:

If $p_{m}$ is the market price for output $y_{m}$ then:

$p=\left[p_{1}, \ldots, p_{m}, \ldots, p_{M}\right] ; 1 \leq m \leq M$ is the price matrix for output

$P^{k}=\boldsymbol{p} \cdot \boldsymbol{y}^{k} ; 1 \leq k \leq K$ is the total turnover of firm $k$.

If $c_{n}$ is the CEC of input $x_{n}$ then:

$\boldsymbol{c}=\left[c_{1}, . ., c_{n}, . ., c_{N}\right] ; 1 \leq n \leq N$ is the cumulative exergy content matrix for input

$C^{k}=\boldsymbol{c} \cdot \boldsymbol{x}^{k} ; 1 \leq k \leq K$ is the total cumulative exergy input of firm $k$.

\begin{tabular}{|c|c|c|c|c|}
\hline Input & Quantity & & & Quantity \\
\hline $\mathrm{CO}_{2}$ & $6.4 \mathrm{t} / \mathrm{ha}$ & & & $2,871 \mathrm{MJ} / \mathrm{ha}$ \\
\hline Solar energy & $33,035,217 \mathrm{MJ} / \mathrm{ha}$ & & & $33,035,217 \mathrm{MJ} / \mathrm{ha}$ \\
\hline $\mathrm{H}_{2} \mathrm{O}$ (liquid) & $9,300 \mathrm{t} / \mathrm{ha}$ & & & $465,000 \mathrm{MJ} / \mathrm{ha}$ \\
\hline $\mathrm{HNO}_{3}$ & $21,429 \mathrm{~mol} / \mathrm{ha}$ & & & $932 \mathrm{MJ} / \mathrm{ha}$ \\
\hline Output & Quantity & Exergy content & Quantity & Exergy cost \\
\hline C (sequestered) & $1.5 \mathrm{t} / \mathrm{ha}$ & & - MJ/ha & $98.93 \mathrm{MJ} / \mathrm{kg} \mathrm{CO} 2$ \\
\hline $\mathrm{C}_{3500} \mathrm{H}_{6000} \mathrm{O}_{3000} \mathrm{~N}_{600}$ & $35.71 \mathrm{~mol} / \mathrm{ha}$ & $1,952,280 \mathrm{~kJ} / \mathrm{mol}$ & 69,724 MJ/ha & \\
\hline $\mathrm{H}_{2} \mathrm{O}$ (vapour) & 6,653.76 t/ha & $9.50 \mathrm{~kJ} / \mathrm{mol}$ & 3,511.706 MJ/ha & $4.76 \mathrm{MJ} / \mathrm{kg}$ \\
\hline $\mathrm{H}_{2} \mathrm{O}$ (liquid) & $2,644.51 \mathrm{t} / \mathrm{ha}$ & $0.90 \mathrm{~kJ} / \mathrm{mol}$ & $132,225 \mathrm{MJ} / \mathrm{ha}$ & $0.45 \mathrm{MJ} / \mathrm{kg}$ \\
\hline $\mathrm{O}_{2}$ & $4.86 \mathrm{t} / \mathrm{ha}$ & $3.97 \mathrm{~kJ} / \mathrm{mol}$ & $603 \mathrm{MJ} / \mathrm{ha}$ & $1.12 \mathrm{MJ} / \mathrm{kg}$ \\
\hline
\end{tabular}

The optimal sustainable firm $j$ is defined as:

- Firm $j$ is on the efficiency frontier, $\theta^{j}=1$;

- $\forall k ; 1 \leq k \leq K$ and $k \neq j ;\left.{ }^{C^{j}}\right|_{p^{j}}<c^{c^{k}} /{ }_{p^{k}}$

Table 4

Inputs and outputs of 1 ha European forest, with indication of the exergy cost of the outputs. 
The sustainable efficiency (SE) for firm $k$ is thus:

$S E=C^{j} /_{P^{j}} \cdot P^{k} /_{C^{k}}={ }^{C^{j}} /_{P^{j}} \cdot P^{P^{k}} /_{\theta^{k} C^{k}} \cdot \theta^{k}=A E \cdot \theta^{k}$.

Here, $\theta^{k}$ is the production efficiency derived from the DEA analysis for firm $\mathrm{k}$. AE is the Allocative Efficiency, it describes the distance of the efficient firm on the DEA frontier to the optimal sustainable firm $\mathrm{j}$. Contrary to $\theta^{k}$, the transition along the frontier to firm $\mathrm{j}$ requires substitutions between input resources to achieve the optimal sustainable situation. The allocative efficiency AE describes thus the potential efficiency increase by modifying the allocation of inputs.

\section{References}

Abusoglu A, Kanoglu M. Exergoeconomic analysis and optimization of combined heat and power production: a review. Renew Sustain Energy Rev 2009;13:2295-308.

Acosta-Alba I, Van der Werf HM. The use of reference values in indicator-based methods for the environmental assessment of agricultural systems. Sustainability 2011;3: 424-42.

Apaiah RK, Linnemann AR, van der Kooi HJ. Exergy analysis: a tool to study the sustainability of food supply chains. Food Res Int 2006;39:1-11.

Ayres R. On the life cycle metaphor: where ecology and economics diverge. Ecol Econ 2004;48:425-38.

Bakshi BR. A thermodynamic framework for ecologically conscious process systems engineering. Comput Chem Eng 2000;24:1767-73.

Banerjee A, Tierney M. Comparison of five exergoenvironmental methods applied to candidate energy systems for rural villages in developing countries. Energy 2011;36:2650-61.

Baral A, Bakshi BR. Thermodynamic metrics for aggregation of natural resources in life cycle analysis: insight via application to some transportation fuels. Environ Sci Technol 2010;44:800-7.

Bastianoni S, Nielsen SN, Marchettini N, Jørgensen SE. Use of thermodynamic functions for expressing some relevant aspects of sustainability. Int J Energy Res 2005;29: 53-64.

Bastianoni S, Facchini A, Susani L, Tiezzi E. Emergy as a function of exergy. Energy 2007;32:1158-62.

Bencze S, Keresztényi I, Varga B, Kőszegi B, Balla K, Gémesné-Juhász A, et al. Effect of $\mathrm{CO}_{2}$ enrichment on canopy photosynthesis, water use efficiency and early development of tomato and pepper hybrids. Acta Agron Hung 2011;59:275-84.

Benetto E, Tiruta-Barna L, Perrodin Y. Combining lifecycle and risk assessments of mineral waste reuse scenarios for decision making support. Environ Impact Assess Rev 2007; $27: 266-85$

Berbigier P, Bonnefond JM, Mellmann P. CO2 and water vapour fluxes for 2 years above Euroflux forest site. Agr Forest Meteorol 2001;108:183-97.

Berkes F, Folke C. Investing in cultural capital for sustainable use of natural capital. In: Jansson A, Hammer M, Folke C, Costanza R, editors. Investing in natural capital: the ecological economics approach to sustainability Island Press. Washington, DC, USA: Island Press; 1994. p. 128-49.

Bösch M, Hellweg S, Huijbregts M, Frischknecht R. Applying cumulative exergy demand (CExD) indicators to the ecoinvent database. Int J Life Cycle Assess 2007;12:181-90.

Bozell JJ. Feedstocks for the future-biorefinery production of chemicals from renewable carbon. CLEAN-Soil Air Water 2008;36:641-7.

Brehmer B, Struik PC, Sanders J. Using an energetic and exergetic life cycle analysis to assess the best applications of legumes within a biobased economy. Biomass Bioenergy 2008;32:1175-86.

Brown M, Bardi E. Handbook of emergy evaluation folio 3: emergy of ecosystems. Center for Environmental Policy Environmental Engineering Sciences; 200194.

Buchgeister J. Exergoenvironmental analysis - a new approach to support the design for environment of chemical processes? Chem Eng Technol 2010;33:593-602.

Chen G, Jiang M, Yang Z, Chen B, Ji X, Zhou J. Exergetic assessment for ecological economic system: Chinese agriculture. Ecol Model 2009;220:397-410.

Christopher K, Dimitrios R. A review on exergy comparison of hydrogen production methods from renewable energy sources. Energy Environ Sci 2012;5:6640-51.

Coelli T, Rao DSP, O'Donnell CJ, Battese GE. An introduction to efficiency and productivity analysis. 2nd ed. Springer Verlag; 2005.

Corning PA, Kline SJ. Thermodynamics, information and life revisited, part I: 'To be or entropy'. Syst Res Behav Sci 1998a;15:273-95.

Corning PA, Kline SJ. Thermodynamics, information and life revisited, part II: 'Thermoeconomics' and 'control information'. Syst Res Behav Sci 1998b;15:453-82.

Daniel SE, Tsoulfas GT, Pappis CP, Rachaniotis NP. Aggregating and evaluating the results of different environmental impact assessment methods. Ecol Indic 2004;4:125-38.

De Meester S, Callewaert C, De Mol E, Van Langenhove H, Dewulf J. The resource footprint of biobased products: a key issue in the sustainable development of biorefineries. Biofuels Bioprod Bioref 2011;5:570-80.

De Meester S, Demeyer J, Velghe F, Peene A, Van Langenhove H, Dewulf J. The environmental sustainability of anaerobic digestion as a biomass valorization technology. Bioresour Technol 2012;121:396-403.

Dewulf J, Van Langenhove H. Assessment of the sustainability of technology by means of a thermodynamically based life cycle analysis. Environ Sci Pollut Res 2002a;9:267-73.
Dewulf JP, Van Langenhove HR. Quantitative assessment of solid waste treatment systems in the industrial ecology perspective by exergy analysis. Environ Sci Technol 2002b;36:1130-5.

Dewulf J, Van Langenhove H, Mulder J, van den Berg MMD, van der Kooi HJ, de Swaan Arons J. Illustrations towards quantifying the sustainability of technology. Green Chem 2000;2:108-14.

Dewulf J, Van Langenhove H, Van de Velde B. Exergy-based efficiency and renewability assessment of biofuel production. Environ Sci Technol 2005;39:3878-82.

Dewulf J, Bösch ME, Meester BD, Vorst GVd, Langenhove HV, Hellweg S, et al. Cumulative Exergy Extraction from the Natural Environment (CEENE): a comprehensive Life Cycle Impact Assessment method for resource accounting. Environ Sci Technol 2007; 41:8477-83.

Dewulf J, Van Langenhove H, Muys B, Bruers S, Bakshi BR, Grubb GF, et al. Exergy: its potential and limitations in environmental science and technology. Environ Sci Technol 2008;42:2221-32.

Dincer I. The role of exergy in energy policy making. Energy Policy 2002;30:137-49.

Evans A, Strezov V, Evans TJ. Assessment of sustainability indicators for renewable energy technologies. Renew Sustain Energy Rev 2009;13:1082-8.

Fatih Demirbas M. Biorefineries for biofuel upgrading: a critical review. Appl Energy 2009;86:S151-61.

Fisher B, Turner RK, Morling P. Defining and classifying ecosystem services for decision making. Ecol Econ 2009;68:643-53.

Fonseca JC, Marques JC, Paiva AA, Freitas AM, Madeira V, Jørgensen SE. Nuclear DNA in the determination of weighing factors to estimate exergy from organisms biomass. Ecol Model 2000;126:179-89.

Gasparatos A, El-Haram M, Horner M. A critical review of reductionist approaches for assessing the progress towards sustainability. Environ Impact Assess Rev 2008;28: 286-311.

Gasparatos A, El-Haram M, Horner M. Assessing the sustainability of the UK society using thermodynamic concepts: part 2. Renew Sustain Energy Rev 2009;13:956-70.

Goedkoop M, Spriensma R, van Volkshuisvesting M, en Milieubeheer RO, Communicatie CD. The eco-indicator 99: a damage oriented method for life cycle impact assessment Ministerie van Volkshuisvesting, Ruimtleijke Ordening en Milieubeheer; 1999.

Gontier M, Balfors B, Mörtberg U. Biodiversity in environmental assessment-current practice and tools for prediction. Environ Impact Assess Rev 2006;26:268-86.

Gowdy J, Erickson JD. The approach of ecological economics. Camb J Econ 2005;29: 207-22.

Hammond AL, Adriaanse A, Rodenburg E, Bryant D, Woodward R. Environmental indicators: a systematic approach to measuring and reporting on environmental policy performance in the context of sustainable development. Washington, DC: World Resources Institute; 1995.

Hau JL, Bakshi BR. Expanding exergy analysis tot account or ecological inputs. In: Engineering DoC, editor. Ohio State University; 2003.

Hau JL, Bakshi BR. Promise and problems of emergy analysis. Ecol Model 2004;178 215-25.

Hepbasli A. A key review on exergetic analysis and assessment of renewable energy resources for a sustainable future. Renew Sustain Energy Rev 2008;12: 593-661.

Hoang V-N, Alauddin M. Analysis of agricultural sustainability: a review of exergy methodologies and their application in OECD countries. Int J Energy Res 2011;35: 459-76.

Hoang V-N, Rao DSP. Measuring and decomposing sustainable efficiency in agricultural production: a cumulative exergy balance approach. Ecol Econ 2010;69:1765-76.

Huang L, Chen G, Zhang Y, Chen B, Luan S. Exergy as a unified measure of water quality. Commun Nonlinear Sci Numer Simul 2007;12:663-72.

Illge L, Hahn T, Figge F. Applying and extending the sustainable value method related to agriculture - an overview. European Association of Agricultural Economists; 2008.

Jørgensen SE. Integration of ecosystem theories: a pattern. Kluwer Academic Pub; 2002. Jørgensen SE. Eco-exergy as sustainability. Wit Pr/Computational Mechanics; 2006.

Jørgensen SE. Evolution and exergy. Ecol Model 2007;203:490-4.

Jorgensen SE, Svirezhev YM. Towards a thermodynamic theory for ecological systems. 1st ed. Pergamon; 2004.

Jorgensen SE, Xu L, Costanza R. Handbook of ecological indicators for assessment of ecosystem health; 2004.

Junginger M, de Wit M, Sikkema R, Faaij A. International bioenergy trade in the Netherlands. Biomass Bioenergy 2008;32:672-87.

Kaushik S, Reddy VS, Tyagi S. Energy and exergy analyses of thermal power plants: a review. Renew Sustain Energy Rev 2011;15:1857-72.

Kim D. A new thermoeconomic methodology for energy systems. Energy 2010;35: 410-22.

Kim S-M, Oh S-D, Kwon Y-H, Kwak H-Y. Exergoeconomic analysis of thermal systems Energy 1998;23:393-406.

Kirova-Yordanova Z. Application of the exergy method to environmental impact estimation: the ammonium nitrate production as a case study. Energy 2010;35: 3221-9.

Kline SJ. The low-down on entropy and interpretive thermodynamics: for the students and teachers of the subject. DCW Industries; 1999.

Lems S, Kooi HJ, Arons JS. Quantifying technological aspects of process sustainability: a thermodynamic approach. Clean Technol Environ Policy 2003;5:248-53.

Liao W, Heijungs R, Huppes G. Is bioethanol a sustainable energy source? An energy-, exergy-, and emergy-based thermodynamic system analysis. Renew Energy 2011;36:3479-87.

Melis A. Solar energy conversion efficiencies in photosynthesis: minimizing the chlorophyll antennae to maximize efficiency. Plant Sci 2009;177:272-80.

Nardo M, Saisana M, Saltelli A, Tarantola S, Hoffman A, Giovannini E. Handbook on constructing composite indicators: methodology and user guide. OECD Publishing; 2005. 
Neupane B, Halog A, Lilieholm RJ. Environmental sustainability of wood-derived ethanol: a life cycle evaluation of resource intensity and emissions in Maine, USA. J Cleaner Prod 2013;44:77-84.

Nzihou A, Stanmore B. The fate of heavy metals during combustion and gasification of contaminated biomass - a brief review. J Hazard Mater 15 July 2013;256-257:56-66.

Odum HT. Environmental accounting: emergy and environmental decision making. John Wiley \& Sons; 1996.

Odum HT, Brown MT, Brandt-Williams S. Folio\# 1: introduction and global budget. Handbook of Emergy Evaluation: A Compendium of Data for Emergy Computation Issued in a Series of Folios. Gainesville: Center for Environmental Policy, Univ of Florida; 2000.

Özilgen M, Sorgüven E. Energy and exergy utilization, and carbon dioxide emission in vegetable oil production. Energy 2011;36:5954-67.

Pick D, Dieterich M, Heintschel S. Biogas production potential from economically usable green waste. Sustainability 2012;4:682-702.

Raugei M. Emergy indicators applied to human economic systems - a word of caution. Ecol Model 2011;222:3821-2.

Rezende FC, Frizzone JA, Oliveira RF, Pereira AS. CO2 and irrigation in relation to yield and water use of the bell pepper crop. Sci Agric 2003;60:7-12.

Rosen M. A concise review of exergy-based economic methods. 3rd IASME/WSEAS international Conference on Energy \& Environment. UK: University of Cambridge; 2008.

Rubio Rodríguez MA, Ruyck JD, Díaz PR, Verma VK, Bram S. An LCA based indicator for evaluation of alternative energy routes. Appl Energy 2011:88:630-5.

Sciubba E. Beyond thermoeconomics? The concept of Extended Exergy Accounting and its application to the analysis and design of thermal systems. Int J Exergy 2001;1:68-84.

Sciubba E. On the second-law inconsistency of emergy analysis. Energy 2010;35 3696-706.

Sciubba E. A revised calculation of the econometric factors $\alpha$ - and $\beta$ for the extended exergy accounting method. Ecol Model 2011;222:1060-6.

Sciubba E, Wall G. A brief commented history of exergy, from the beginnings to 2004. Int Thermodyn 2007; 10:1-26.

Sewalt M, Toxopeus M, Hirs GG. Thermodynamics based sustainability concept. Int J Thermodyn 2001;4:35-41.

Silow EA, Mokry AV. Exergy as a tool for ecosystem health assessment. Entropy 2010;12 902-25.

Simpson AP, Edwards CF. An exergy-based framework for evaluating environmental impact. Energy 2011;36:1442-59.

Soares SR, Toffoletto L, Deschênes L. Development of weighting factors in the context of LCIA. J Cleaner Prod 2006;14:649-60.

Stougie L, Van der Kooi $\mathrm{H}$. The relation between exergy and sustainability according to literature. ELCAS; 2011.

Szargut J. Exergy method, technical and ecological applications. Gateshead: WIT Press; 2005.

Szargut J, Morris D, Steward F. Exergy analysis of thermal, chemical and metallurgical processes. Berlin: Hemisphere Puhl Corp, New York: Springer Verlag, 1988.

Szargut J, Valero A, Stanek W, Valero A. Towards an international legal reference environment. In: Kjelstrup S, Hustad JE, Tsatsaronis G, Gundersen T, Rosjorde A, editors. Trondheim: ECOS; 2005

Taelman S, DE Meester S, Roef L, Michiels M, Dewulf J. The environmental sustainability of microalgae as feed for aquaculture: a life cycle perspective. Bioresour Technol 2013. http://dx.doi.org/10.1016/j.biortech.2013.08.044. (Available online 14 August 2013, in press).

Talens Peiró L, Villalba Méndez G, Sciubba E. Gabarrell i Durany X. Extended exergy accounting applied to biodiesel production. Energy 2010;35:2861-9.

Tremblay N, Gosselin A. Effect of carbon dioxide enrichment and light. HortTechnology 1998;8:524-8.

Tsatsaronis G. Application of thermoeconomics to the design and synthesis of energy plants. Exergy, energy system analysis and optimization. In: Frangopoulos Christo A, editor. Encyclopaedia of Life Support Systems (EOLSS), Developed under the Auspices of the UNESCO. Oxford, UK: Eolss Publishers; 2006.

Tsatsaronis G, Pisa J. Exergoeconomic evaluation and optimization of energy systems-application to the CGAM problem. Energy 1994;19:287-321.

Ukidwe NU. Thermodynamic input-output analysis of economic and ecological systems for sustainable engineering. The Ohio State University; 2005.

Urban RA, Bakshi BR. 1,3-Propanediol from fossils versus biomass: a life cycle evaluation of emissions and ecological resources. Ind Eng Chem Res 2009;48:8068-82.

Valero A. Exergy accounting: capabilities and drawbacks. Energy 2006;31:164-80.

Valero A, Botero E. An assessment of the earth's clean fossil exergy capital based on exergy abatement costs; 2002151-7.
Valero A, Lozano MA, Munoz M. A general theory of exergy saving: part I. On the exergetic cost. In: Gaggioli RA, editor. Computer-aided engineering of energy systems. Second law analysis and Modelling U.S.A.: The American Society of Mechanical Engineers; 1986.

Valero A, Lozano MA, Serra L, Tsatsaronis G, Pisa J, Frangopoulos C, et al. CGAM problem: definition and conventional solution. Energy 1994;19:279-86.

Van Dael M, Van Passel S, Pelkmans L, Guisson R, Reumermann P, Luzardo NM, et al. A techno-economic evaluation of a biomass energy conversion park. Appl Energy 2013;104:611-22.

van der Werf HMG, Tzilivakis J, Lewis K, Basset-Mens C. Environmental impacts of farm scenarios according to five assessment methods. Agric Ecosyst Environ 2007;118: 327-38.

Van Passel S, Meul M. Multilevel and multi-user sustainability assessment of farming systems. Environ Impact Assess Rev January 2012;32(1):170-80.

Van Passel S, Van Huylenbroeck G, Lauwers L, Mathijs E. Sustainable value assessment of farms using frontier efficiency benchmarks. J Environ Manage 2009;90:3057-69.

Verdesca D, Federici M, Torsello L, Basosi R. Exergy-economic accounting for sea-coastal systems: a novel approach. Ecol Model 2006;193:132-9.

Wang J-J, Jing Y-Y, Zhang C-F, Zhao J-H. Review on multi-criteria decision analysis aid in sustainable energy decision-making. Renew Sustain Energy Rev 2009;13: 2263-78.

Warner JC, Cannon AS, Dye KM. Green chemistry. Environ Impact Assess Rev 2004;24: 775-99.

Weiland P, Verstraete W, Van Haandel A. Biomass digestion to methane in agriculture: a successful pathway for the energy production and waste treatment worldwide. Biofuels: John Wiley \& Sons, Ltd; 2009171-95.

Yang Q, Chen B, Ji X, He YF, Chen GQ. Exergetic evaluation of corn-ethanol production in China. Communications in Nonlinear Science and Numerical Simulation. 2009;14: 2450-61.

Yi H, Hau JL, Ukidwe NU, Bakshi BR. Hierarchical thermodynamic metrics for evaluating the environmental sustainability of industrial processes. Environ Prog 2004;23: 302-14.

Zah R, Böni H, Gauch M, Hischier R, Lehmann M, Wäger P. Life cycle assessment of energy products: environmental assessment of biofuels. Report produced under a contract from the Swiss Federal Office for Energy, the Swiss Federal Office for the Environment and the Swiss Federal Office for Agriculture. Switzerland: Empa Technology and Society Lab Bern; 2007. p. 19.

Zah R, Faist M, Reinhard J, Birchmeier D. Standardized and simplified life-cycle assessment (LCA) as a driver for more sustainable biofuels. J Cleaner Prod 2009;17(Supplement 1):S102-5.

Zhang B, Chen G. Physical sustainability assessment for the China society: exergy-based systems account for resources use and environmental emissions. Renew Sustain Energy Rev 2010;14:1527-45.

Zhu P, Feng X, Shen R. An extension to the cumulative exergy consumption applied to environmental impact analysis of industrial processes. Process Saf Environ Prot 2005;83:257-61.

Zhu XG, Long SP, Ort DR. What is the maximum efficiency with which photosynthesis can convert solar energy into biomass? Curr Opin Biotechnol 2008;19:153-9.

Dries Maes obtained a Master in Engineering Sciences and specializes since 2003 in the economic assessment of energy efficiency in industrial installation and the sustainability assessment of biomass and renewable energy projects. As a consultant, he guided several companies and organisation in their transition towards a more sustainable business. Since 2010, he is a doctoral researcher at Hasselt University, focusing on economic and sustainability assessment of innovative cleantech solutions.

Steven Van Passel obtained a Master of Bioscience Engineering and a Master in Economics at the Katholieke Universiteit Leuven (Belgium). He obtained his PhD at the University of Ghent (Belgium) where he analysed the sustainability performance of farms using an efficiency approach. Since 2007, he works at the Faculty of Business Economics of Hasselt University. His research concentrates on the economic and sustainability assessment of micro-systems (e.g. firm level). As an ecological and environmental economist, he is interested in conceptual and methodological aspects of assessing sustainability for clean technologies. His research group applies these approaches to a wide variety of innovative technologies for climate change response, remediation, renewable energy and sustainable production. 